DOI: https://dx.doi.org/10.21123/bsj.2021.18.4(Suppl.).1492

\title{
Temperature Stress on Physiological and Morphological Traits in Rhizophora apiculata
}

\author{
Baseem M. Tamimi ${ }^{1 *}$ (D) Wan Juliana W. A. ${ }^{1,2}$ (D) \\ Che Radziah Che Mohd. Zain ${ }^{1}$ (D)
}

\author{
Nizam M. S. ${ }^{1,2}$ (iD
}

\begin{abstract}
${ }^{1}$ Faculty of Science and Technology, Universiti Kebangsaan Malaysia, 43600 UKM Bangi, Selangor, Malaysia.
${ }^{2}$ Institute for Climate Change, Universiti Kebangsaan Malaysia, 43600 UKM Bangi, Selangor, Malaysia.

*Corresponding author: baseemtamimi@siswa.ukm.edu.my

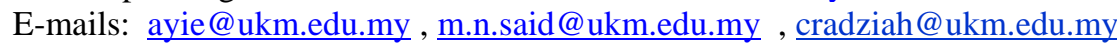

Received 6/9/2020, Accepted 4/4/2021, Published 20/12/2021

This work is licensed under a Creative Commons Attribution 4.0 International License.

\begin{abstract}
:
Global warming has had considerable effects on vital ecosystems, which has also been caused by increased temperatures and $\mathrm{CO}_{2}$ that follow changes in different abiotic factors, which poses threats to mangrove forests environment. This research was conducted to examine the physiological and morphological characteristics of the Rhizophora apiculata mangrove regarding higher air temperature for the variety of tree species that respond to climate change. Seedlings were cultivated for three months in regulated growth chambers with three varying temperatures of $38^{\circ} \mathrm{C}, 21^{\circ} \mathrm{C}$ under $\mathrm{CO}_{2}$ at $450 \mathrm{ppm}$, and ambient $\mathrm{CO}_{2}$ concentration i.e., $450 \pm 20 \mathrm{ppm}$ under average temperature at $28^{\circ} \mathrm{C}$ as the control condition. The plants were treated every 48 hours with $3 \mathrm{~L}$ of saline water of $28 \mathrm{ppt}$. After two weeks at high temperature, the mangrove showed positive results for all parameters. The temperature variations resulted in major variations, such as negative for increased temperature resulting in extreme damage to many samples while positive for decreased temperature resulting in slow development. The physiological results show decreased photosynthesis rates compared to controlled samples. These findings indicate that low photosynthetic capability levels could have occurred due to reduced $\mathrm{CO}_{2}$ fixative reaction mechanism, photosynthetic pigment material, and the discrepancy between respiratory and photosynthesis rate.
\end{abstract}

Keywords: Climate change, Global warming, Mangrove, Photosynthetic, Growth.

\section{Introduction:}

Studies and scientific knowledge about the growth of plants under natural conditions may be numerous and varied. The need to increase scientific knowledge about extreme environmental conditions affects the survival, vitality, and production of plants, especially in the context of frequent climate changes and global warming conditions. Elevated concentrations of atmospheric carbon dioxide $\left(\mathrm{CO}_{2}\right)$ and subsequent rising temperatures alter the global atmosphere ${ }^{1,2}$. Since these influences are indicators of plants' photosynthesis levels ${ }^{3,4}$, any changes in the climate and atmospheric composition would have a significantlly effect on the planetary biodiversity ${ }^{5}$. Due to the rising global population and growing industrial development, atmospheric $\mathrm{CO}_{2}$ concentration has risen over the past century. As previous research has suggested, making this a prominent and evident of Global Environmental
Change leads to warmer global temperatures (Fig.1). The IPCC report notes that $20-40 \%$ of the world's people live in regions that have experienced at least one warming season of more than $1.5^{\circ} \mathrm{C}^{6}$ and the 0.3 to $0.6^{\circ} \mathrm{C}$ increase in the average annual surface air temperature in the last century (Fig.2). This indicates the direct impact of current changes in the atmosphere on the expected temperature rise ${ }^{7}$.

Nevertheless, the essential information in (a) seasonal and diurnal variations, (b) extreme occurrence, timing and period (e.g., low or high temperatures, early or late frosts), and (c) climate variation may be overshadowed by large mean annual temperature prediction's changes ${ }^{8}$. One example is that recent forecasts have anticipated more warming in late autumn and winter in mid to high northern latitudes, where little or none occurs (or even cooling in mid-latitudes) during summer ${ }^{9}$, which may impact the increasing duration of the 
season. Note that there are already signs of a shift in the growing season length ${ }^{10}$. In addition, another example is the clear proof that the rise in minimum temperature at nighttime is almost double the change in average, over land ${ }^{7}$. Plant developments are significantly influenced by the current changes in the diurnal cycles due to an even temperature shift over 24 hours. However, these extensive global mean temperature forecasts misrepresent crucial characteristics of the natural and controlled ecosystem ${ }^{2}$.

Mangroves are remarkable ecosystems that are valuable economically and ecologically. They are located at the interface of land and sea, in tropical mudflats. $R$. apiculata is the most common mangrove species. It grows gregariously in swamps flooded by normal high tide. It is the dominant canopy member in fewer saline sites along the estuarine floodplain ${ }^{11}$. The pioneering work, as well as more recent studies ${ }^{12}$ have shown that all species of mangrove tested thus far can exclude at least $80 \%$ of the external salt during seawater uptake, and with even greater efficiency $(>95 \%)$ in $R$. apiculata species. Root systems of mangroves remain upright and stable when soft soils. The Rhizophora is often defined in the top and ground distribution of root biomass, in which the majority of live root biomass seems to be above ground ${ }^{13}$. Much more investigation is required. Evaluation of the impacts of extreme environmental factors on the ability of mangrove plants to survive would explain the current geographical distribution of mangrove habitats that has gone beyond the tropical and subtropical latitudinal range ${ }^{14}$. An abrupt shift in climate would threaten the natural mangrove ecosystems, including Rhizophora apiculata species assemblages, which play a significant role in climate change mitigation and act as natural buffers to protect coastlines from hurricanes and severe winds ${ }^{15}$.

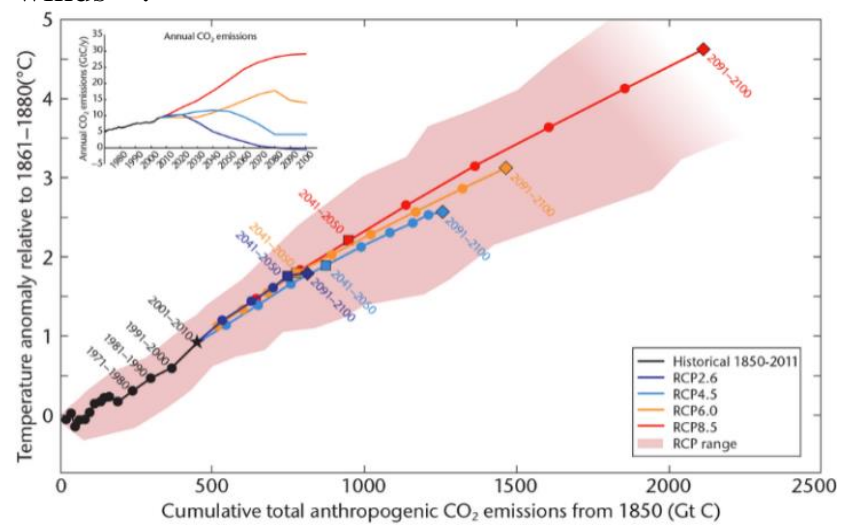

Figure 1. Explanatory annotations from the annual average midday temperature increase in the Mediterranean region and the global temperature rise, Empirical Scaling Relationship (ESR) ${ }^{16}$.

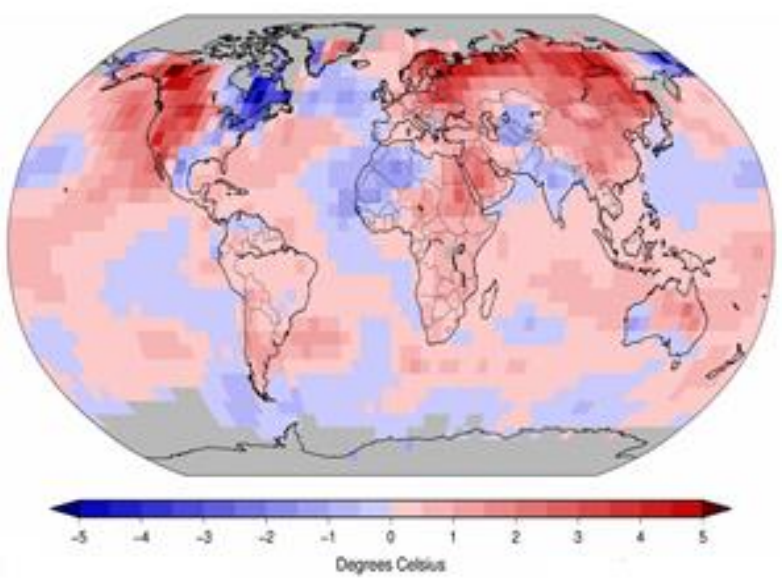

Figure 2. Land and ocean temperature departure (with respect to a 1981-2010 base period) ${ }^{17}$.

\section{Global Warming in Malaysia}

Malaysia's atmosphere is considered tropical as it is located close to the equator, which ranges from $0^{\circ} 60^{\prime} \mathrm{N}$ to $6^{\circ} 40^{\prime} \mathrm{N}$ and $99^{\circ} 35^{\prime} \mathrm{E}$ to $119^{\circ} 25^{\prime}$ E. The warm and moist all year-round Malaysia's climate is known as equatorial (tropical rainforest) climates. The interference of mountains in Sumatra, Borneo, and Peninsular Malaysia affects the maritime monsoon ${ }^{18}$. In coastal lowlands, the monthly average air temperature is between $26-28^{\circ} \mathrm{C}$ (Fig.3) with slight differences in various months or across various latitudes and between $75 \%$ and $90 \%$ monthly relative humidity. Changes in temperature in Malaysia are between + $0.3^{\circ} \mathrm{C}$ to $+4.5^{\circ} \mathrm{C}$ (Fig.4), while changes in rainfall are between $-30 \pm 30 \%{ }^{16}$. Malaysia's peninsula climate differs from its east, depending on the coming monsoon accompanied by rain, particularly from the China Sea and the Northern Pacific ${ }^{19}$. The impacts of climate change are an issue of concern in Malaysia. According to the 2012 Climate Change Performance Index (CCPI), Malaysia ranks among the least in climate protection performance. This raises possible threats to domestic food safety and the region's export revenues from plantation crops since any detrimental climate affects farm productivity ${ }^{20}$. Evidence abounds on the fact that Malaysia has undergone long-term erratic climate change with a rapid acceleration in recent decades. Also, El Nino disasters have caused dry, hot weather and unusual minimal precipitation during these respective years ${ }^{18}$ (Fig.3). 


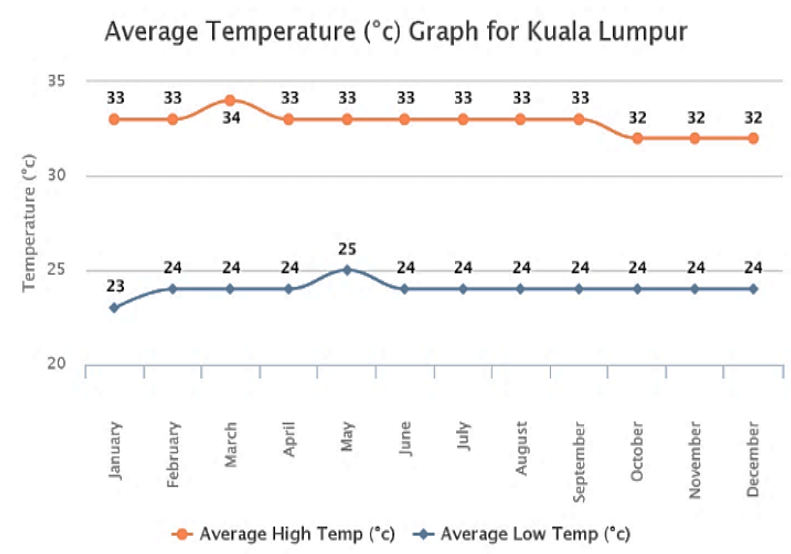

Figure 3. PRECIS Average annual temperature anomaly ${ }^{19}$.

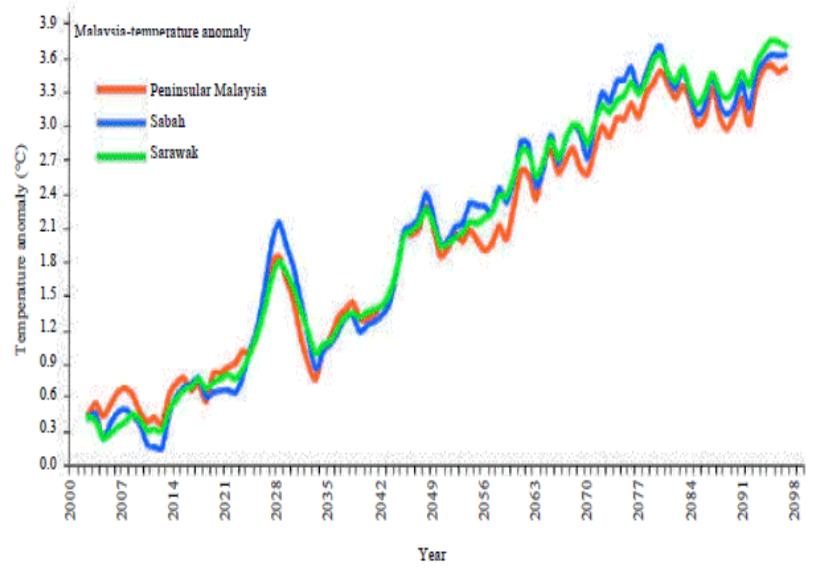

Figure 4. PRECIS simulation (2001-2099) annual temperature anomaly ${ }^{19}$.

The protection and regeneration of mangroves and related marine habitats play a significant role in strategies for responding to climate change. Mangroves are useful in attempts to combat climate change and also influential in adapting to climate change ${ }^{21}$. In correspondence to the impact mangroves possess in adapting to climate change, further resources must be incorporated into their growth plans as the adaptation to climate change is a rising issue in most international development initiatives ${ }^{8}$. Therefore, the purpose of this research is to examine the impacts of increasing temperatures on the growth of the most prevalent and widely spread mangrove forests of the Rhizophoraceae family, found in Malaysia ${ }^{22}$. The mangrove forests must be protected, in particular, due to their economic value and its crucial part in sustaining the ecosystem and the variety of species ${ }^{23}$.

\section{Materials and Methods:}

This study was carried out at the Tropical Ecophysiology Lab in UKM, Bangi, Malaysis $\left(2^{\circ}\right.$ $\left.55^{\prime} 12.03 \mathrm{~N}, 101^{\circ} 47^{\prime} 2.99 \mathrm{E}\right)$. The station comprises of the Plant Growth Chamber (model GC-202C), which monitored and controlled the relative humidity $( \pm 1.0 \%$ at $80 \%)$, lighting $\left(1000 \mu \mathrm{mol} \mathrm{m}^{-2}\right.$ $\left.\mathrm{s}^{-1} \mathrm{PAR}\right)$, temperature set at $21 / 18^{\circ} \mathrm{C}$ and $38 / 35^{\circ} \mathrm{C}$ (day/night) as well as $\mathrm{CO}_{2}$ sensors $(450 \pm 30 \mathrm{ppm})$ for the entire three months of the project's duration. Seedlings of mangrove plants with soil were gathered from Kuala Gula, Perak (4.924012, 100.459581) at the age of three months. This mangrove seedling grows up in $(42-62 \mathrm{~cm})$ box sizes, which then planted into three groups, having seven samples in each box. These samples then tested two weeks later regarding its physical development, where those listed as 'good health' were moved to the chambers for plant production. The first group exposed to plant growth chamber levels at $21^{\circ} \mathrm{C}+\mathrm{CO}_{2} 450 \mathrm{ppm}$, while the second group was at $38^{\circ} \mathrm{C}+\mathrm{CO}_{2} 450 \mathrm{ppm}$, depending on the temperature recorded in Malaysia $\left(24-35^{\circ} \mathrm{C}\right)$ (Fig. 3). The temperature then increased and decreased by $\pm 3^{\circ} \mathrm{C}$ (Fig. 4) for the third group control in the ambient area, according to Malaysian temperature mentioned in earlier studies. Also, the plants watered every 48 hours with $3 \mathrm{~L}$ of saline water (28 ppt) with no fertilizer given. All damaged or dead plant materials were extracted from the mesocosms. Simultaneously, all visible faunas (for example, crabs and snails) extracted to prevent confounding impacts on soil burrowing, , activities and other herbivore. The mangrove seedlings labeled under treatments and groups, where any variations in the seedlings' health documented qualitatively.

\section{Design of Experimental and Growth Measurement}

The growth parameters of plants were assessed to investigate mangrove responses towards increased air temperature. The analysis of the leaves number, branches number, the plant's height, and the stems' diameter corresponding to all the morphological parameters were performed manually with the foot and log rule calliper. On the other hand, the rate of photosynthesis was calculated utilizing a Li-cor 6400 at 11 am for all Li-cor measurements. Before each measurement, leaves were equilibrated in the cuvette at saturating PPFD $\left(1000 \mu \mathrm{mol} \mathrm{m} \mathrm{m}^{-2} \mathrm{~s}^{-1} \mathrm{PAR}\right)$, temperature $28^{\circ} \mathrm{C}$, $\mathrm{CO}_{2}$ at $400 \mu \mathrm{mol} \mathrm{mol}^{-1}$. The chlorophyll concentration was determined by utilizing the standard procedure to reduce the volume of acetones ${ }^{24}$. Following from there, $0.1 \mathrm{~g}$ of mangrove plant leaves were cut into tiny pieces (about $2 \mathrm{~mm}$ ) and placed in a test tube. Then, $20 \mathrm{ml}$ of $80 \%$ acetone was added to the test tube. A shaker homogenized the mixture and incubated it in the dark for two days. Chlorophyll $b$ and $a$ 
concentration were assessed by utilizing a $663 \mathrm{~nm}$ and $645 \mathrm{~nm}$ wavelength spectrophotometer, respectively. The concentrations of each chlorophyll were calculated using the following equations ${ }^{25 ; 26}$ :

$\mathrm{C}_{\text {chl-a }}=12.7 \mathrm{~A}_{663^{-}}-2.69 \mathrm{~B}_{645}$

$\mathrm{C}_{\text {chl-b }}=22.9 \mathrm{~A}_{645}-4.68 \mathrm{~B}_{663}$

Total chlorophyll $=\mathrm{C}_{\text {chl-a }}+\mathrm{C}_{\text {chl-b }}$

For stomata, the responses were measured using the Variable Pressure Scanning Electron Microscope (SEM) Model (Zeiss/LEO1450VP, Oberkochen, Germany, 2010). Fresh and dried seedling weights were measured on a digital scale, yielding dry weight after drying in the oven at $65^{\circ} \mathrm{C}$ for seven days. Measurements were performed three times, where the first measurement was conducted on July 1, 2016 quantitatively, the second on August 17, 2016 (after 45 days), while the final analyses was performed on October 1, 2016 (after 90 days).

\section{Data Analysis}

SAS software (Release 9.4) was used to the experimental data that was subjected to (ANOVA) and Duncan's multiple range test (DMRT) with a substantial difference level of $\alpha=0.05$.

\section{Results and Discussion: \\ Morphological responses}

Seedlings growth parameters demonstrated varied reactions based on the number of treatment days (plant height, number of leaves, number of branches, stem's diameter, and area of leaves) between different temperature treatments (Fig.5). Morphological parameter observations were shown to increase with significant differences between treatments after 1-45 days of exposure. Also, subsequent observations after 45-90 days of treatment demonstrated different responses based on various temperatures and the number of treatment days (Table 1). The highest plant height was recorded on day 45 for the temperature of $38^{\circ} \mathrm{C}$ at $63 \mathrm{~cm}$ average, but as a result of the constant heat till the 90th day, many samples died, and time showed significant effects since the plant height decreased. However, the plant growth at low temperatures was slow, which scored good health for all parameters (Fig.5) compared to ambient (Table 1). Also, the mean diameter of stems under temperature $38^{\circ} \mathrm{C}$ was highly significant and increased better compared to the temperature of $21{ }^{\circ} \mathrm{C}$ and ambient. The rest of the morphological parameters, namely the number of leaves, branches, and the leaves size, recorded an apparent decrease in all these parameters at a high temperature of $38^{\circ} \mathrm{C}$. In contrast, the low temperature was ineffective and did not record high differences except for the number of branches, which recorded a slight rise in the number of branches at a low temperature of $21^{\circ} \mathrm{C}$. Upon comparing results with the ambient control, there was a noticeable increase in these three parameters. The number of branches recorded the highest number at 10.7, while the number of leaves was at a rate of 13.7. At the same time, the leave size recorded $65.3 \mathrm{~cm}^{2}$ (Table 1), where an increase in leaf area was observed in the ambient area. However, the extent of the growth differed under different temperature conditions, where the leaf area's increment did not occur in all leaves and in most cases. Factors related to leaf areas, such as the photosynthesis and the transpiration rate, have a direct effect on plant productivity, making the leaf area a key variable in plant-based physiologic studies, photosynthetic effectiveness, light interception, and evapotranspiration.

\section{Physiological responses}

The findings indicated that under elevated various temperatures, the photosynthesis cycle has been weak and inefficient. Responses to photosynthesis decreased gradually at 1-45 days, based on various temperatures and the number of treatment days. The photosynthesis responses decreased in exposure to temperature $38^{\circ} \mathrm{C}$ for final experimental at 90 days, while the plants under control restored in photosynthesis responses (Fig.6 A). The findings showed that based on the number of treatment days, the overall chlorophyll under $\mathrm{CO}_{2}$ concentration and various temperatures exhibited different responses. For all treatments, the total amount of chlorophyll gradually increased throughout 1-45 days, as displayed in (Fig. 6 B). At 90 days of exposure, the total chlorophyll decreased significantly under $\mathrm{CO}_{2}$ concentration and $38^{\circ} \mathrm{C}$ temperature, meanwhile the plants under control increased less in comparison to 1-45 days (Fig.6 B). Stomata show various responses concerning different temperatures to minimize the transpiration and water loss processes by closing stomata opening for high temperature, while the lower temperature reduced the small size of the stomata compared to samples of ambient area (see Fig.7). 
Table 1. Mangrove seedlings $R$. apiculata growth parameters with subject to various air temperatures.

\begin{tabular}{|c|c|c|c|c|c|c|c|c|c|}
\hline \multirow[t]{2}{*}{ Parameters } & \multicolumn{3}{|c|}{1 Day } & \multicolumn{3}{|c|}{45 Days } & \multicolumn{3}{|c|}{90 Days } \\
\hline & $\begin{array}{l}\underset{\infty}{\sim} \\
\stackrel{\infty}{\circ} \\
\stackrel{0}{0}\end{array}$ & $\underset{\stackrel{+}{N}}{\stackrel{-1}{0}}$ & $\begin{array}{l}\frac{D}{3} \\
\frac{0}{\frac{0}{D}} \\
\frac{1}{7}\end{array}$ & $\begin{array}{l}\vec{w} \\
\underset{\infty}{-1} \\
\stackrel{0}{0}\end{array}$ & $\underset{\text { N }}{\stackrel{-1}{0}}$ & $\begin{array}{l}\frac{D}{3} \\
\frac{0}{\frac{D}{D}} \\
\frac{0}{\partial}\end{array}$ & $\begin{array}{l}\overrightarrow{-1} \\
\underset{\infty}{\infty} \\
\stackrel{0}{0}\end{array}$ & $\begin{array}{l}\underset{\sim}{N} \\
\stackrel{-1}{0}\end{array}$ & $\begin{array}{l}\frac{D}{3} \\
\frac{0}{0} \cdot \frac{1}{0} \\
\frac{1}{7}\end{array}$ \\
\hline Height (cm) & $\begin{array}{l}57 \\
\pm 0.5^{\mathrm{d}}\end{array}$ & $\begin{array}{c}56.5 \pm 0 . \\
5^{d}\end{array}$ & $\begin{array}{c}58 \\
\pm 0.3^{\mathrm{dc}}\end{array}$ & $\begin{array}{c}63 \\
\pm 0.45^{\mathrm{a}}\end{array}$ & $\begin{array}{c}57 \pm 0.8 \\
9^{d}\end{array}$ & $\begin{array}{c}60.5 \\
\pm 0.94^{b}\end{array}$ & $\begin{array}{c}62.3 \\
\pm 0.99^{\mathrm{a}}\end{array}$ & $59 \pm 0.9^{c}$ & $\begin{array}{c}61.5 \\
\pm 0.93^{\mathrm{ab}}\end{array}$ \\
\hline Branches Number & $\begin{aligned} & 4.7 \\
\pm & 0.57^{d}\end{aligned}$ & $4.7 \pm 0.5$ & $\begin{array}{c}4.3 \\
\pm 0.56^{\mathrm{d}}\end{array}$ & $\begin{array}{c}6.3 \pm 0.5 \\
7^{c}\end{array}$ & $\underset{c}{6.7 \pm 0.9}$ & $7.3 \pm 1^{b}$ & $\begin{array}{c}7.5 \\
\pm 0.95^{b}\end{array}$ & $8 \pm 1^{b}$ & $\begin{array}{c}10.7 \\
\pm 0.57^{\mathrm{a}}\end{array}$ \\
\hline Leaves Number & $\begin{array}{c}8.7 \pm 0.5 \\
7^{b}\end{array}$ & $8 \pm 0.5^{b c}$ & $\begin{array}{c}7.7 \\
\pm 0.3^{\mathrm{bc}}\end{array}$ & $\begin{array}{c}7.3 \\
\pm 0.55^{c}\end{array}$ & $9 \pm 0.98^{b}$ & $9 \pm 0.98^{b}$ & $6.3 \pm 1^{c}$ & $\begin{array}{c}8.9 \pm 0.7 \\
8^{b}\end{array}$ & $\begin{array}{c}13.7 \pm 0.4 \\
5^{\mathrm{a}}\end{array}$ \\
\hline Stems Diameter & $\begin{array}{c}2.3 \\
\pm 0.26^{c}\end{array}$ & $\begin{array}{c}2.57 \pm 0 . \\
5^{b}\end{array}$ & $\begin{array}{c}2.6 \\
\pm 0.25^{\mathrm{b}}\end{array}$ & $\begin{array}{l}2.55 \\
\pm 0.4^{b}\end{array}$ & $\begin{array}{c}2.59 \pm 0 . \\
2^{\mathrm{b}}\end{array}$ & $\begin{array}{c}2.69 \\
\pm 0.27^{\mathrm{a}}\end{array}$ & $\begin{array}{c}2.7 \\
\pm 0.22^{\mathrm{a}}\end{array}$ & $\begin{array}{c}2.61 \pm 0 . \\
4^{b}\end{array}$ & $\begin{array}{c}2.76 \\
\pm 0.26^{\mathrm{a}}\end{array}$ \\
\hline Leaves area $\left(\mathrm{cm}^{2}\right)$ & $\begin{array}{c}59 \pm 0.5 \\
5^{d c}\end{array}$ & $\begin{array}{c}60.3 \pm 0 . \\
1^{c}\end{array}$ & $\begin{array}{c}60.3 \pm 0 . \\
5^{c}\end{array}$ & $\begin{array}{l}59.3 \pm 0 . \\
1^{\mathrm{dc}}\end{array}$ & $\begin{array}{c}60.6 \pm 0 . \\
2^{c}\end{array}$ & $\begin{array}{c}62.5 \pm 0.9 \\
2^{b}\end{array}$ & $58.3 \pm 1^{d}$ & $\begin{array}{c}60 \pm 0.2 \\
8^{c}\end{array}$ & $65.3 \pm 0.9^{\mathrm{a}}$ \\
\hline
\end{tabular}

Note: The mean \pm standard deviation (SD) followed by different alphabet in each row denotes a significant difference using DMRT at $(\mathrm{p}<0.05)$.
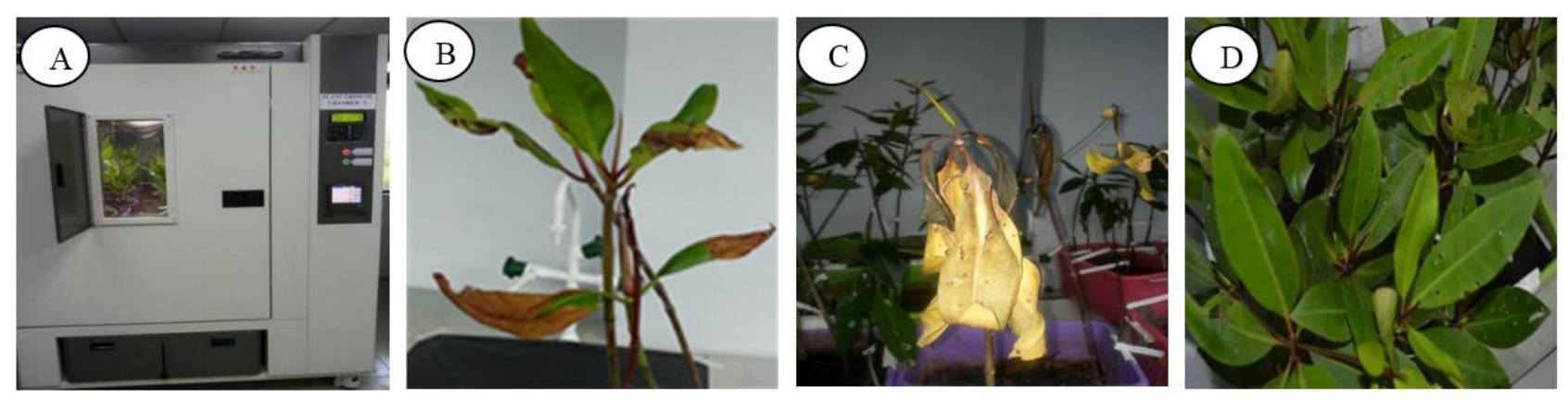

Figure 5. The impact of high temperature on mangrove plants inside the growth chambers show different responses depending on days of treatments (A) Plant growth chamber (B) Mangrove plants response at 45 days at temperature $38^{\circ} \mathrm{C}(\mathrm{C})$ Mangrove plants response at 90 days at temperature $38^{\circ} \mathrm{C}$, while (D) Mangrove plants response at 90 days at temperature $21^{\circ} \mathrm{C}$.
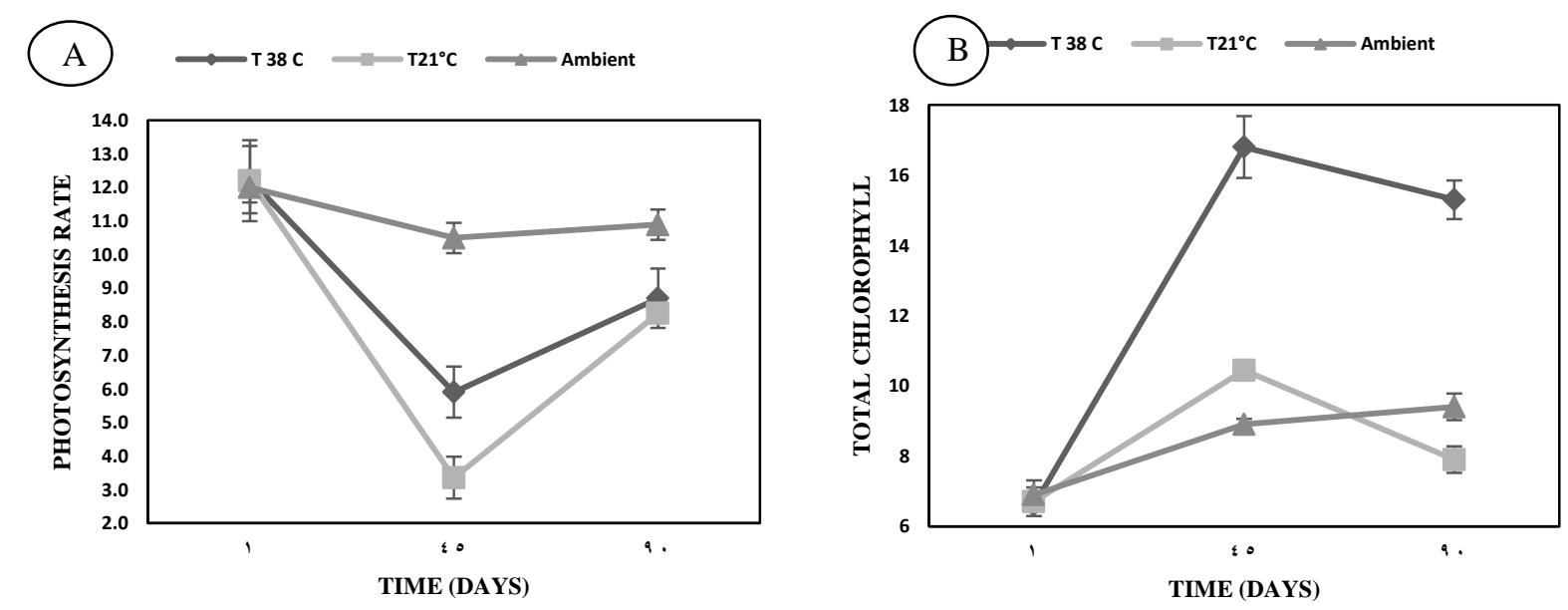

Figure 6. Comparative responses of ambient area and different air temperature of (A) Photosynthesis Rate, and (B) Total Chlorophyll of mangrove plants R. apiculata 


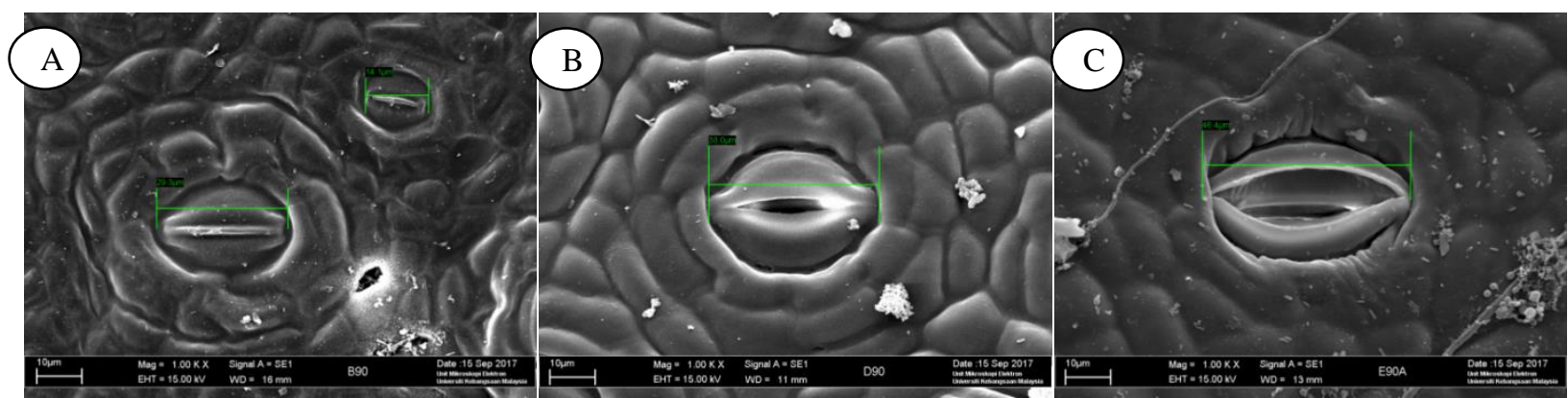

Figure 7. Comparative stomata responses of different temperature (A) $38^{\circ} \mathrm{C}$, (B) $21^{\circ} \mathrm{C}$ and (C) ambient of mangrove seedlings leaf (R. apiculata).

The mangrove plant's fresh with dry shoot weight and fresh with dry root weight demonstrated a substantial difference in all parameters. The fresh mangrove shoot weight was higher for temperature $21^{\circ} \mathrm{C}$ at 84.1 grams than 22.4 grams in temperature $38^{\circ} \mathrm{C}$ and the ambient area for fresh 67.2 grams and dry shoot weight 19.9 grams (Table 2). The plants' dry shoot weight was higher in temperature $21^{\circ} \mathrm{C}$, which is 23.3 grams compared to 7.5 grams at temperature $38^{\circ} \mathrm{C}$. The mean fresh mangrove root weight at temperature $38^{\circ} \mathrm{C}$ averaged at 24 grams, while temperature $21^{\circ} \mathrm{C}$ at 73.9 grams. On the other hand, the dry root weight at temperature $38^{\circ} \mathrm{C}$ averaged at 6.1 grams, while in temperature $21^{\circ} \mathrm{C}$, the average was higher at 14.7 grams. For the ambient area (controlled) of fresh 48.1 grams and dry root weight 10.6 grams, the percentage increased in the growth of the mangrove plant was in ascending order of fresh shoot weight, fresh root weight, dry root weight, and dry shoot weight (Table 2).

Table 2. Responses of mangrove seedlings $R$. apiculata to ambient and different temperature.

\begin{tabular}{|c|c|c|c|c|}
\hline & \multicolumn{2}{|c|}{ Shoot } & \multicolumn{2}{|c|}{ Roots } \\
\hline Treatment & Fresh weight (g) & Dry weight (g) & Fresh weigh (g) & Dry weight (g) \\
\hline Temperature $38^{\circ} \mathrm{C}$ & $22.4 \pm 0.7^{\mathrm{c}}$ & $7.5 \pm 1^{\mathrm{c}}$ & $24 \pm 0.57^{c}$ & $6.1 \pm 0.4^{\mathrm{c}}$ \\
\hline Temperature $21^{\circ} \mathrm{C}$ & $84.1 \pm 0.1^{\mathrm{a}}$ & $23.3 \pm 1.2^{\mathrm{a}}$ & $73.9 \pm 0.3^{\mathrm{a}}$ & $14.7 \pm 0.7^{\mathrm{a}}$ \\
\hline Ambient & $67.2 \pm 0.3^{\mathrm{b}}$ & $19.9 \pm 1^{b}$ & $48.1 \pm 0.1^{\mathrm{b}}$ & $10.6 \pm 0.1^{\mathrm{b}}$ \\
\hline
\end{tabular}

Note: The mean \pm standard deviation $(\mathrm{SD})$ followed with various letter of the same column of treatment that significantly tested by using (DMRT) at level of $\alpha=0.05$.

The findings revealed major variations in the parameters tested influencing different temperatures, where different responses were shown based on the number of treatment days. An observed response was obtained on the morphological parameters corresponding to various temperatures, particularly after the first 45 days. However, the occurrence of high temperatures possessed a negative effect on the growth of mangroves, which was evident at the end (90 days) of the investigation. little of samples was died during this treatment., while several morphological parameters have been affected, particularly the numbers of leaves that have seen a substantial decrease influencing the rate of photosynthesis ${ }^{27 ; 28}$ given the rise in chlorophyll concentration. This suggests that the temperature rise has a physiological impact on the plant via the impact on the plant's biological activities, particularly enzymes ${ }^{29}$ (Rubisco enzyme is accountable for the
Calvin Cycle of $\mathrm{CO}_{2}$ ). The Rubisco, however, restricts photosynthesis when electron transport constraints prevail, and the photosynthesis rate can fall rapidly at rise of temperatures ${ }^{30}$. As for the low temperature, its effect was prolonged, leading to slow growth and the survival of all the plants. This is one of the reasons why the studied morphological parameters did not show great differences in comparison to samples at rise of temperatures. It was affected photosynthesis compared to ambient area $^{30}$.

In the early stages of development, climate change on mangrove plants can be deemed harmful by intervening abiotic and biotic factors in global warming. These findings include confirmatory proof that the temperature effects and other environmental factors are negative and harmful, merely influencing the geographical spread and survival of mangrove plants ${ }^{31}$. The interaction of the other factors can also possess various effects. 
Therefore, research in this area should be increased to enhance the knowledge of the relationship between factors that may influence the duration of the growing season. As a matter of fact, there is evidence of changes in the length of the growing season ${ }^{10}$, the magnitude of heat stress, and time periods that were affected by diurnal cycles. It has also greatly affected the plant development in comparison to even changes in temperature over 24 hours.

\section{Research Limitations:}

- It is not possible to provide an environment precisely like that in the future.

- The size of the growth chambers restricts the size and specific type of samples.

- The size of the growth chambers is specific, limiting the box sizes used to cultivate the samples as well as the amount of water inside the boxes.

\section{Research Contributions:}

Significant contributions were made throughout conducting this study, such as gathering the largest amount of information on the effect of temperature that may contribute to the conservation and greater utilization of mangrove forests. Along with the environment and ways of adapting to environmental changes, it helps to determine the appropriate places to increase mangrove forests and pay more attention to these forests.

\section{Potential Future Works:}

Studies and scientific knowledge about the growth of plants under natural conditions may be varied. However, there is a need to increase the scientific understanding of extreme environmental conditions, which are often not considered, affecting the survival, vitality, and production of plants, especially in the context of frequent climate change and global warming conditions. Overall, the study of plant response to environmental stress has been a leading and essential issue, which may help understand the plant's response and explain the geographical distribution, thus performing both the growth and production of the state of an environmental gradient. Understanding the plant's response to stress may be necessary as well as knowing the real impact of the interactions of environmental factors that lead to understanding the adaptation and acclimation in plants.

\section{Conclusions:}

Generally, this study has shown that increasing air temperatures have a significant impact on the growth of mangrove plants. Due to the history of Global Environmental Change, ways to evolve them to any climate change and different temperature ranges in other regions in the world. Thus, it is critical to examine the plant's response with regards to various temperature ranges. The light, water, and nutrient availability have equal importance in determining and understanding the effects of increased $\mathrm{CO}_{2}$. Nonetheless, the studies mentioned earlier may already contain information on several of those interactions. Directly, the increase in air temperature prevented acclimation and that is one of the main threats that resulted in its non-survival, given water supplies and a similar environmental climate. Moreover, the rapid reactions to elevated air temperatures during the initial growth stages, as seedlings establishment, can be significant determinants in plant regeneration. Scientific knowledge about the effect of extreme environmental conditions could help us to meet the El Nino risks faced by Malaysia and the risks of climate change.

\section{Acknowledgements:}

The authors gratefully thank and acknowledged to research found by Sime Darby Foundation (FRGS/1/2016/STWN10/UKM/02/1) and also thank staffs of PPSSSA, FST, UKM to complete this research project.

\section{Authors' declaration:}

- Conflicts of Interest: None.

- We hereby confirm that all the Figures and Tables in the manuscript are mine ours. Besides, the Figures and images, which are not mine ours, have been given the permission for republication attached with the manuscript.

- Ethical Clearance: The project was approved by the local ethical committee in UKM Bangi, Selangor, Malaysia.

\section{Authors' contributions:}

Baseem M. Tamimi, Wan Juliana W. A., Nizam M. S., and Che Radziah Che Mohd. Zain contributed to the design and implementation of the research, the analysis of the results, and the writing of the manuscript.

\section{References:}

1. Asbridge E, Lucas R, Accad A, Dowling R. Mangrove response to environmental changes predicted under varying climates: case studies from Australia. Curr Forestry Rep. 2015;1(3): 178-194.

2. Cavanaugh KC, Kellner JR, Forde AJ, Gruner DS, Parker JD, Rodriguez W. Poleward expansion of mangroves is a threshold response to decreased frequency of extreme cold events. PNAS. 2014;111(2): 723-727.

3. Keenan TF, Williams CA. The terrestrial carbon sink. AR. 2018;43: 219-243.

4. Martin AR, Doraisami M, Thomas SC. Global patterns in wood carbon concentration across the 
world's trees and forests. Nature Geoscience. 2018;11(12): 915-920.

5. Fatichi S, Pappas C, Zscheischler J, Leuzinger S. Modelling carbon sources and sinks in terrestrial vegetation. New Phytologist. 2019; 221(2): 652-668.

6. Tollefson J. IPCC says limiting global warming to $1.5 \mathrm{C}$ will require drastic action. Nature. 2018 Oct 8;562(7726):172-3.

7. Quéré CL, Andrew RM, Friedlingstein P, Sitch S, Pongratz J, Manning AC. Global carbon budget 2017. Earth Syst. Sci. Data. 2018;10(1): 405-448.

8. Quetin GR, Swann ALS. Sensitivity of leaf area to interannual climate variation as a diagnostic of ecosystem function in CMIP5 carbon cycle models. JCLI. 2018;31(20): 8607-8625.

9. Kattenberg A. Climate models: projections of future climate. AMS, Boston, MA (United States) 1996.

10. Lovenduski NS, Bonan GB. Reducing uncertainty in projections of terrestrial carbon uptake. Environ. Res. Lett. 2017;12(4): 44020.

11. Ball MC, Cochrane M, Rawson M. Growth and water use of the mangroves Rhizophora apiculata and $R$. stylosa in response to salinity and humidity under ambient and elevated concentrations of atmospheric $\mathrm{CO}_{2}$. PC\&E.1997; 20: 1158-1166. doi:10.1046/j.1365-3040.1997.d01-144.x

12. Paliyavuth C, Clough B, Patanaponpaiboon P. Salt uptake and shoot water relations in mangroves. Aquatic Botany. 2004; 78(4): 349-360. doi:10.1016/j.aquabot.2004.01.002.

13. Ong JE, Gong WK, Wong CH. Allometry and partitioning of the mangrove, Rhizophora apiculata. Forest Ecology and Management . 2004; 188(1-3): 395-408.

14. Feller IC, Friess DA, Krauss KW, Lewis RR. The state of the world's mangroves in the $21^{\text {st }}$ century under climate change. Hydrobiologia. 2017; 803(1): $1-12$.

15. Van Lavieren H, Spalding M, Alongi D, Kainuma M, Clüsener-Godt M, Adeel Z. Securing the future of mangroves, a policy brief. UNSECO Hamilton, on Canada. 2012; p53.

16. Seneviratne SI, Phipps SJ, Pitman AJ, Hirsch AL, Davin EL, Donat MG, et al. Land radiative management as contributor to regional-scale climate adaptation and mitigation. Nat. Geosci. 2018;11(2): 88-96.

17. NOAA. National Climatic Data Centre. 2015; https://www.ncdc.noaa.gov/sotc/global/201504.

18. Kaffashi S. Assessing the impacts of climate change on paddy production in Malaysia. Res. J. Environ. Sci. 2014; 8(6): 331-341.

19. Rahman HA. Climate Change Scenarios In Malaysia: Engaging The Public. IJoM-NS. 2018;1(2): 55-77.

20. Murad W, Molla RI, Mokhtar MB, Raquib A. Climate change and agricultural growth: an examination of the link in Malaysia. IJCCSM. 2010.

21. Crooks S, Herr D, Tamelander J, Laffoley D, Vandever J. Mitigating climate change through restoration and management of coastal wetlands and near-shore marine ecosystems: challenges and opportunities. World Bank 2011.
22. Wan Juliana WA, Razali MS, Latiff A. Distribution and rarity of Rhizophoraceae in Peninsular Malaysia. Mangrove Ecosystems of Asia. 2014; 23-36. Springer.

23. Hassan MK, Jintana V, Kuittinen S, Pappinen A. Management Practices and Aboveground Biomass Production Patterns of Rhizophora apiculata Plantation: Study from a Mangrove Area in Samut Songkram Province, Thailand. Bioresources. 2018;13(4): 7826-7850.

24. Nurdin CM, Ikeu TJ. Chlorophyll level of Various Geen Leaves and Copperchlorophyll Derivates and its Charaterization. JGP. 2009;12(1): 11-12.

25. Arnon DI. Copper enzymes in isolated chloroplasts. Polyphenoloxidase in Beta vulgaris. Plant Physiol.1949; 24(1): 1.

26. Mackinney G. Absorption of light by chlorophyll solutions. J. biol. Chem. 1941;140(2): 315-322.

27. Friend AD, Eckes-Shephard AH, Fonti P, Rademacher TT, Rathgeber CBK, Richardson AD, et al. On the need to consider wood formation processes in global vegetation models and a suggested approach. Ann. For. Sci. 2019; 76(2): 49.

28. Zheng Y, Li F, Hao L, Shedayi AA, Guo L, Ma C, et al. The optimal $\mathrm{CO}_{2}$ concentrations for the growth of three perennial grass species. BMC pb. 2018;18(1): 27.

29. Seftigen K, Frank DC, Björklund J, Babst F, Poulter B. The climatic drivers of normalized difference vegetation index and tree-ring-based estimates of forest productivity are spatially coherent but temporally decoupled in Northern Hemispheric forests. Global Ecol. Biogeogr. 2018;27(11): 13521365.

30. Yamori W, Hikosaka K, Way DA. Temperature response of photosynthesis in $\mathrm{C} 3, \mathrm{C} 4$, and CAM plants: temperature acclimation and temperature adaptation. Photosynth Res. 2014;119(1-2): 101-117.

31. Tamimi B, WanJuliana WA, Nizam MS, Zain CRCM. Elevated $\mathrm{CO}_{2}$ Concentration and Air Temperature Impacts on Mangrove Plants (Rhizophora apiculata) Under Controlled Environment. IJS. 2019; pp.16581666. 


\section{إجهاد درجة الحرارة على الصفات الفسيولوجية والمظهرية في أثجار القرم

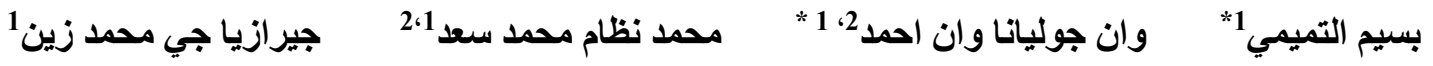

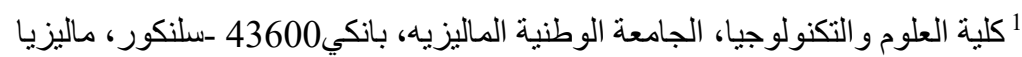

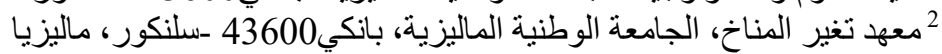

الاحتباس الحراري له تأثيرات كبيرة على النظم البيئية الحيوية، والتي تسببت أيضًا في ارتفاع درجات الحرارة وثناني أكسيد

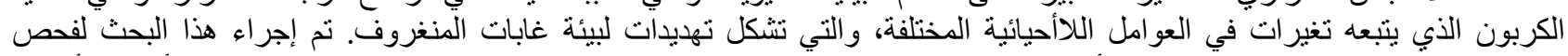

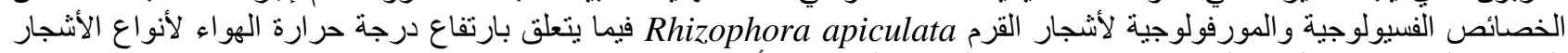
المتنو عة التي تستجيب لتغير المناخ.

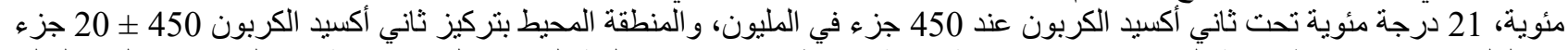

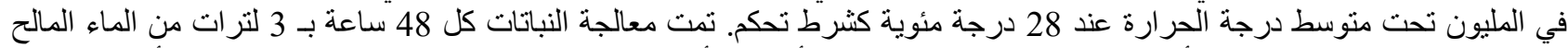

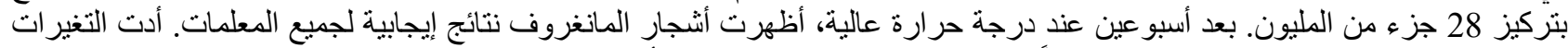

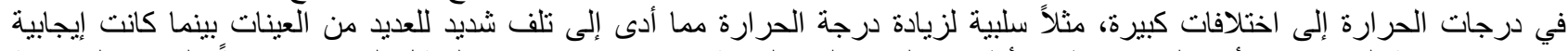

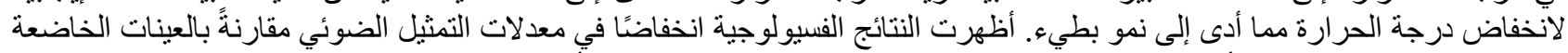

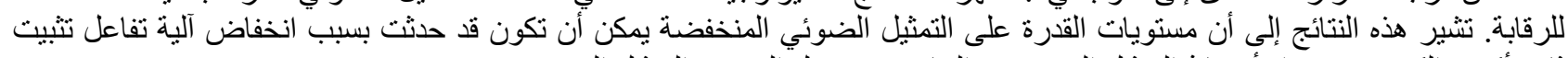

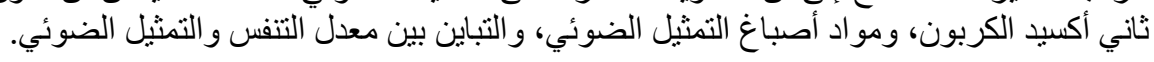

الكلمات المفتاحية: التغيرات المناخية، الاحتباس الحراري، المانغروف، التمثيل الضونئي، النمو. 